\title{
New Species of Endemic Kleptoparasitic Spiders of the Genus Argyrodes (Araneae: Theridiidae) in the Hawaiian Islands ${ }^{1}$
}

\author{
Malia Rivera ${ }^{2}$ and Rosemary G. Gillespie ${ }^{3}$
}

\begin{abstract}
This study examined the endemic species of kleptoparasitic spiders in the genus Argyrodes from the Hawaiian Islands, a lineage previously known in the archipelago from only a single described species, Argyrodes bawaiiensis Simon. Here, two additional endemic species are described, $A$. ilipoepoe Rivera and Gillespie, n. sp., and $A$. laba Rivera and Gillespie, n. sp., with their biogeographical patterns, and the allotype female and paratypes of $A$. hawaiiensis are designated. As with $A$. hawaiiensis, both new species are commonly found as kleptoparasites on the sheet webs of large nocturnal spiders in the genus Orsonwelles (Linyphiidae). Hawaiian Argyrodes are characterized by small and rounded abdomens, unpronounced clypeal projections, and variably long fangs. Argyrodes hawaiiensis; A. ilipoepoe, n. sp.; and $A$. laha, n. sp., include all the known endemic representatives of the group in the Hawaiian Islands, which mostly occur in wet and mesic forests.
\end{abstract}

The Hawailan archipelago is well known for being host to many diverse terrestrial arthropod assemblages, yet many of these lineages, including those of the endemic spider fauna (Gillespie et al. 1998, Gillespie 1999), have remained poorly understood. Although work on Hawaiian spiders has recently had an increased focus, efforts have largely been limited to groups with extensive species radiations, for example those in the genera Tetragnatha Latreille (Tetragnathidae) (Karsch 1880, Simon 1900, Okuma 1988, Gillespie 1991, 1992, 1994, 2002, 2003), Mecaphesa Simon (Thomisidae) (Simon 1900, Suman

\footnotetext{
${ }^{1}$ This work has been supported by grants from the Ecology, Evolution, and Conservation Biology Program and the Haumana Graduate Program at the University of Hawai'i at Mānoa. Manuscript accepted 14 July 2009.

${ }^{2}$ Hawai'i Institute of Marine Biology, University of Hawai'i at Mānoa, 46-007 Lilipuna Road, Kāne'ohe, Hawai'i 96744 (phone: 808-235-9301; fax: 808-235-9300; e-mail: maliar@hawaii.edu).

${ }^{3}$ Environmental Science, 137 Mulford Hall, University of California, Berkeley, CA 94720.
}

Pacific Science (2010), vol. 64, no. 2:221-231

doi: 10.2984/64.2.221

(C) 2010 by University of Hawai'i Press

All rights reserved
1970, Lehtinen 1993, Garb 1999), and Orsonwelles Hormiga (Linyphiidae) (Hormiga 2002). More recently, a small group of endemic spiders has been discovered in the Hawaiian Islands that belongs to the genus Argyrodes Simon (Theridiidae). The genus Argyrodes is a part of the subfamily Argyrodinae, a large and cosmopolitan lineage of well over 200 described species worldwide that contains spiders with a diverse array of morphological features and foraging behaviors, including kleptoparasitism and free-living araneophagy (Exline and Levi 1962, Whitehouse 1987, Cangialosi 1997).

Taxonomic relationships within the Argyrodinae have been a subject of debate over the last several decades, resulting in several of the originally described genera being collapsed into the single composite genus Argyrodes by Exline and Levi in 1962. However, a number of researchers did not agree with the composite designation and recent cladistic investigations have resulted in the resurrection of five of these genera (Agnarsson 2004). Today, in addition to the genus Argyrodes, several genera (Ariamnes Thorell; Rhomphaea Koch; Faiditus Keyserling; Neosphintharus Exline, 1950; Spheropistha Yaginuma, 1957) are again recognized in the subfamily Argyrodinae, and cladistic support is provided for the 
monophyly of the group (Yoshida 2002, Agnarsson 2004).

In Hawai'i, taxonomic treatments of endemic spiders primarily have been limited to the early descriptions of Simon (1900) and collections of Perkins (1913). In fact, Argyrodinae spiders in the Islands were known from only two species, A. hawaiiensis Simon and Ariamnes corniger Simon. Recently, Gillespie and Rivera (2007) described 10 new endemic species of Hawaiian Ariamnes, a diverse lineage of the subfamily Argyrodinae that appears to have undergone an adaptive radiation in the Islands. The endemic Ariamnes spiders are generally free-living nocturnal araneophages, though some may be facultative kleptoparasites on the sheet webs of the linyphiid spiders of the genus Orsonwelles.

Although the genus Ariamnes contains many diverse endemic species in the Islands, the current study reveals that the endemic members of Hawaiian Argyrodes are limited to only three species. All three appear to be obligate kleptoparasites and to date have been found occurring only in the sheet webs of endemic Orsonwelles species. Despite their close relationship to Ariamnes, the Hawaiian Argyrodes can easily be distinguished by their fundamentally different body forms. Kleptoparasites are very small with rounded abdomens, whereas the free-living araneophages are generally larger, with variably long, slender abdomens. An introduced kleptoparasitic species, Argyrodes argentatus O. P. Cambridge, is also present in the Hawaiian Islands (Beatty 2000) and to date has commonly been found kleptoparasitizing both the orb webs of introduced spiders and the sheet webs of endemic Orsonwelles. Argyrodes argentatus is widely distributed from Madagascar through Southeast Asia and South America (Cambridge 1880, Exline and Levi 1962) and is easy to distinguish from the Hawaiian species. Argyrodes argentatus has been treated extensively elsewhere (Cambridge 1880, 1897, Exline and Levi 1962, Chrysanthus 1963, Zhu and Song 1991). The current study focuses only on the Hawaiian endemic members of the genus Argyrodes and is the second of two descriptive papers of Hawaiian Argyrodinae.
MATERIALS AND METHODS

Morphological measurements were made according to Exline and Levi (1962) on the shape of the carapace, clypeus, fangs, and abdomen. The length of the whole body, carapace, abdomen, and segments of the first leg; the form and organization of the genitalia of both males and females; and the abdominal coloration pattern were also examined for gross morphology. All measurements and illustrations were made with the aid of a camera lucida. Ten to 20 specimens of each species were assessed, and six to 12 individuals per species were measured for variation. Abbreviations are as follows: TL, total length; CL, carapace length; AL, abdomen length; FeI, first femur; FeII, second femur; FeIII, third femur; and TaI, first tarsus.

Genitalia of females were dissected from the abdomen using a fine scalpel and tissue dissolved by treatment with a $35 \% \mathrm{KOH}$ solution for approximately $5 \mathrm{~min}$., followed by several rinses in distilled water. In addition to illustrations, measurements of the epigynes were made with a dissecting microscope equipped with a metric-ruled eyepiece. Dissected epigynes were then placed in microvials along with the female specimen. Palps of males were examined by positioning the specimen under the microscope to allow a ventral view of the palpal organ without having to remove the palp from the body. This was done with the aid of fine sand to hold the spider in place for illustration and measurement.

To complement the type descriptions and illustrations, scanning electron microscopy was used to examine the palps of paratype males from each of the species. Palps were removed from the specimen, placed in capsules, submerged in an alcohol series $(70 \%, 85 \%$, $95 \%$, and $100 \%$ ), and dried using a critical point drier (Autosamdri-810). Palps were then placed on stubs with silver paste, sputter coated with gold, and viewed with an SEM (Hitachi S-800). Holotype male and allotype female specimens of the new species were deposited at the Bernice Pauahi Bishop $\mathrm{Mu}-$ seum in Honolulu, Hawai'i (врвм); all para- 

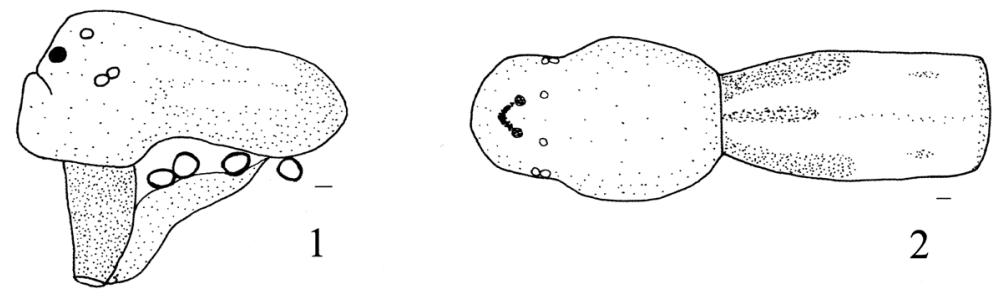

3
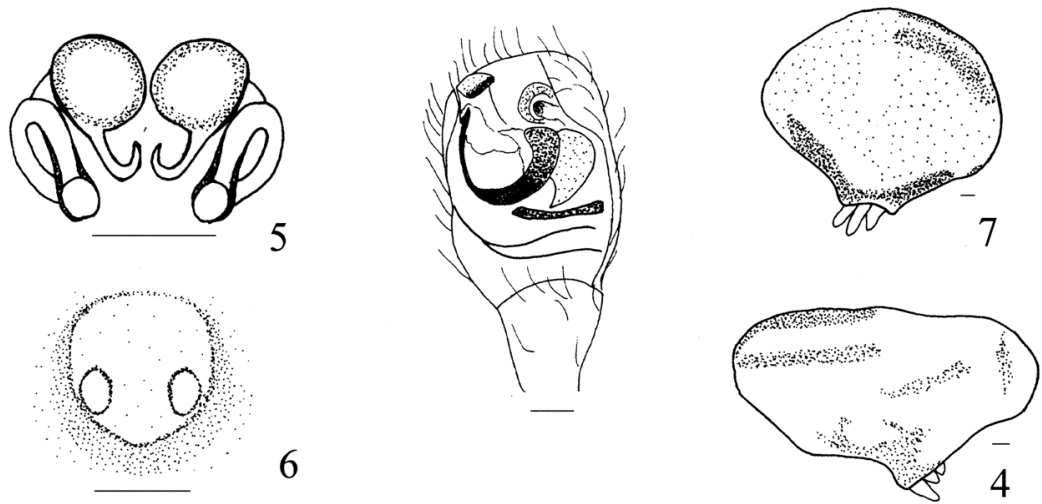

Figures 1-7. Argyrodes hawaiiensis Simon, 1900, from Hawaici. 1-4. Male: (1) cephalothorax in retrolateral view, (2) carapace and abdomen in dorsal view, (3) left palp in ventral view, (4) abdomen in retrolateral view. 5-7. Female: (5) genitalia in dorsal view, (6) epigynum in ventral view, (7) abdomen in retrolateral view. Scale bars equal $0.1 \mathrm{~mm}$.

types were deposited in the Essig Museum of Entomology at the University of California at Berkeley (EMEC).

\section{TAXONOMIC RESULTS}

Family Therididdae Sundevall, 1833

Genus Argyrodes Simon, 1864

Argyrodes hawaiiensis Simon, 1900

Figures 1-7, 22

Argyrodes hawaiiensis Simon, 1900:447, Fauna Hawaiiensis.

type material. Male holotype: Kona, Hawai' $i$, USA $(610 \mathrm{~m})$, in the Natural History Museum, London (examined). Allotype female: Kahauale'a Natural Area Reserve $\left(19.45^{\circ} \mathrm{N}, 155.12^{\circ} \mathrm{W}, 627 \mathrm{~m}\right), \mathrm{M}$. Rivera, 9 March 1998 (new designation).

Note: Vial containing holotype male originally contained a female as well, which has since been identified as Argyrodes argentatus
O. Pickard-Cambridge, an introduction to the Hawaiian Islands.

other material examined. Hawai'i Island: Puna Forest Reserve $\left(19.45^{\circ} \mathrm{N}, 155.10^{\circ}\right.$ W, $612 \mathrm{~m})$, R. G. Gillespie and A. Vandergast, 12 February 1997 (1 male, 1 female). Paratypes (new designation): Hawai'i Island: Laupāhoehoe Natural Area Reserve (19.93 $\left.\mathrm{N}, 155.29^{\circ} \mathrm{W}, 1,131 \mathrm{~m}\right), \mathrm{M}$. Rivera and $\mathrm{M}$. Arnedo, 18 August 1998 (1 male). Laupāhoehoe Natural Area Reserve (19.96 N, 155.27 W, $703 \mathrm{~m})$, M. Rivera and A. Vandergast, 4 November 1998 (1 female). Pu'u Maka'ala, Stainback Highway $\left(19.55^{\circ} \mathrm{N}, 155.20^{\circ} \mathrm{W}\right.$, $936 \mathrm{~m})$, K. Fay and B. Stevens, 7 March 1999 (1 female). Kona (612 m), R. C. L. Perkins, 24 October 1904 (1 male).

Diagnosis. Argyrodes hawaiiensis is similar to $A$. ilipoepoe Rivera and Gillespie, n. sp., in external shape, but the male can easily be distinguished by its much shorter embolus with a serrated, as opposed to smooth, surface (Figures 3, 22). In A. hawaiiensis, the embolus 
makes almost a complete circular turn, but the embolus in $A$. ilipoepoe, n. sp., turns more than a complete circle. The tip of the embolus is pointed in $A$. hawaiiensis but rounded in $A$. ilipoepoe, n. sp. The theridiid tegular apophysis in $A$. bawaiiensis is broader, with a raised, as opposed to a somewhat smooth, texture at the tip. The median apophysis is similar in the two species. Copulatory ducts leading to the seminal receptacles of the female are more heavily sclerotized than those of $A$. ilipoepoe, n. sp., and have a single, elliptical coil.

REDESCRIPTion of MALE. Male (Figures 1-4, 22): In alcohol, carapace light brown with darkened margins, legs brown. Distance from dorsal surface of carapace to cephalic groove equal to distance of cephalic groove to ventral margin of clypeus. Cephalic groove fine, appearing only as slit in lateral view. Length of fangs nearly equal to height of carapace. In dorsal view, carapace slightly wider than abdomen. Abdomen light brown to pale yellow, with three black elliptical patches extending from anterior end, ending approximately midway along dorsal surface of abdomen. Abdomen also dotted with small black and silvery patches. Length of abdomen nearly equal to length of carapace. Embolus wider at base, narrowing toward tip, surface serrated. Theridiid tegular apophysis sclerite extends upward and slightly angled to prolateral side, with tip curled forward. TL, 3.3; CL, 1.7; AL, 1.6; FeI, 4.4; FeII, 4.6; FeIII, 2.8; TaI, 1.4.

DESCRIPTION of FEMAle. Allotype female (new designation) (врвм 17202) (Figures 5-7): Legs, carapace, and abdomen all dark brown. Length from dorsal surface of carapace to ventral margin of clypeus shallower than in male, with cephalic groove more pronounced. Abdomen shorter, deeper, and rounder than in male, with black and silver patches over light brown to yellow background. Dorsal surface of abdomen brown. Epigynum heavily sclerotized, with distinct circular copulatory orifices. Copulatory ducts to seminal receptacles with single elliptical coil and increasing sclerotization toward genital openings. Fertilization ducts hook- shaped. TL, 2.9; CL, 1.2; AL, 1.7; FeI, 2.0; FeII, 2.2; FeIII, 1.4; TaI, 0.9.

VARIATION. Individuals vary only in color and pattern of black and silver patches, overall size, and shape of abdomen. For both males and females, some individuals are light brown to yellow, but others may be dark brown. Most individuals have silvery and black patches on the abdomen, although positions of the patches vary extensively. Some individuals lack the three parallel black ellipses on the dorsal abdomen. Size ranges: (males) TL, 3.0-3.3; CL, 1.4-1.7; AL, 1.51.6; FeI, 3.5-4.4; FeII, 3.6-4.6; FeIII, 2.22.8; TaI, 1.0-1.4; (females) TL, 2.7-3.0; CL, 0.9-1.2; AL, 1.5-1.9; FeI, 2.0-2.4; FeII, 2.22.4; FeIII, 1.3-1.4; TaI, 0.7-0.9.

Distribution. This species has been found only on the island of Hawai' $i$.

haвitat. Occurs in wet and mesic forests.

\section{Argyrodes laba Rivera and Gillespie, n. sp.}

Figures 8-14, 23

TyPe material. Holotype male (врвм 17201): 'Eke Trail, West Maui Mountains $\left(20.93^{\circ} \mathrm{N}, 156.57^{\circ} \mathrm{W}, 826 \mathrm{~m}\right)$, Maui Island, Hawai'i, USA, M. Rivera and M. Heddle, 18 November 1997. Allotype female: Lower Waikamoi, Haleakalā $\left(20.81^{\circ} \mathrm{N}, 156.35^{\circ} \mathrm{W}\right.$, 1,284 m), Maui Island, M. Rivera, 8 November 1996. Paratypes: O'ahu Island: Hawai'i, $\mathrm{Pu}^{6} \mathrm{u}$ 'Ōhi'a Trail, Ko'olau Mountains $\left(21.34^{\circ} \mathrm{N}, 157.81^{\circ} \mathrm{W}, 550 \mathrm{~m}\right), \mathrm{M}$. Rivera, 25 October 1995 (1 male). Mount Tantalus, Ko'olau Mountains $\left(21.33^{\circ} \mathrm{N}, 157.83^{\circ} \mathrm{W}\right.$, $306 \mathrm{~m}$ ), A. Tan, 15 September 1993 (1 male, 1 female). Mount Ka'ala Natural Area Reserve, Wai'anae Mountains $\left(21.52^{\circ} \mathrm{N}\right.$, $\left.158.17^{\circ} \mathrm{W}, 673 \mathrm{~m}\right), \mathrm{M}$. Rivera and M. Arnedo, 21 November 1995 (1 male); M. Rivera, 5 January 1997 (1 female); M. Rivera, 5 April 1997 (1 female). Maui Island: 'Eke Trail, West Maui Mountains $\left(20.93^{\circ} \mathrm{N}\right.$, $\left.156.57^{\circ} \mathrm{W}, 826 \mathrm{~m}\right), \mathrm{M}$. Rivera and M. Heddle, 18 November 1997 (1 female). Lower Waikamoi, Haleakalā $\left(20.81^{\circ} \mathrm{N}, 156.35^{\circ} \mathrm{W}\right.$, 1,284 m), M. Rivera, 8 November 1996; M. Rivera, 4 November 1997; M. Rivera, B. 

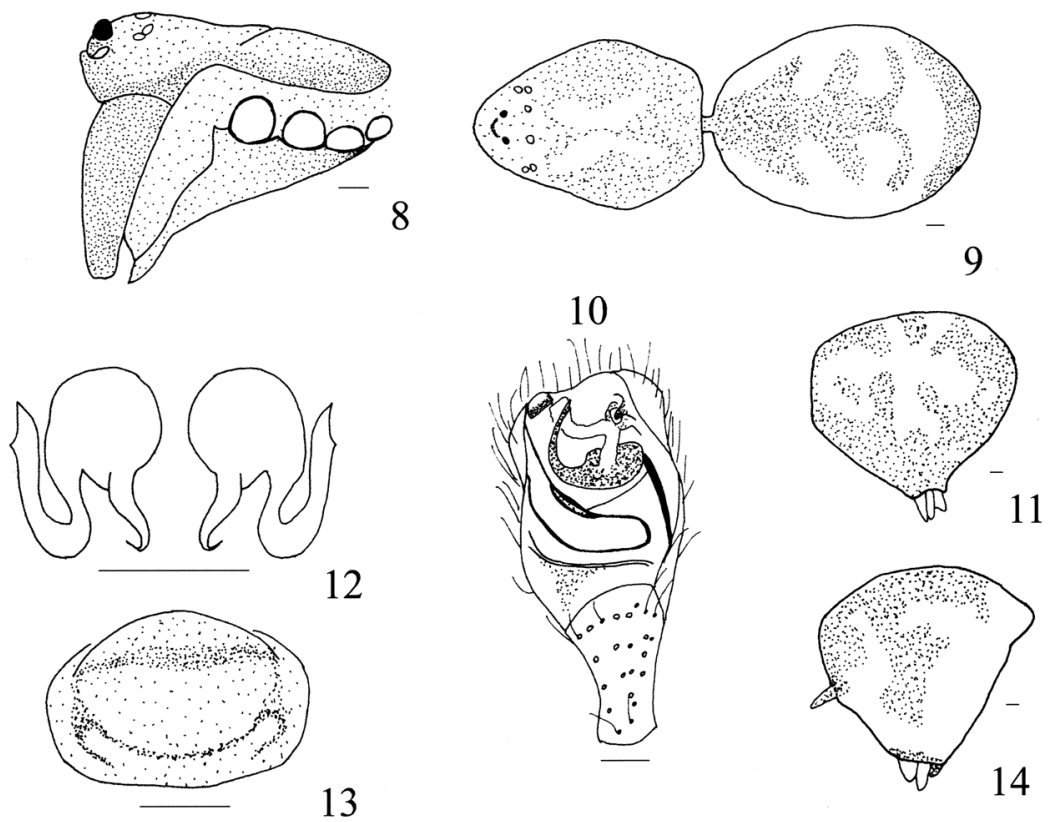

Figures 8-14. Argyrodes laha Rivera and Gillespie, n. sp., from Hawai'i. 8-11. Male holotype: (8) cephalothorax in retrolateral view, (9) carapace and abdomen in dorsal view, (10) left palp in ventral view, (11) abdomen in retrolateral view. 12-14. Female: (12) genitalia in dorsal view, (13) epigynum in ventral view, (14) abdomen in retrolateral view. Scale bars equal $0.1 \mathrm{~mm}$.

Thorsby, and A. Bohonak, 22 November 1997 (1 male, 2 females). Moloka'i Island: Kamakou Natural Area Reserve $\left(21.10^{\circ} \mathrm{N}\right.$, $\left.156.87^{\circ} \mathrm{W}, 1,284 \mathrm{~m}\right)$, C. Ewing, 4 June 1997 (1 male, 1 female).

etymology. The specific epithet, regarded as a noun in apposition, is a Hawaiian word meaning common and refers to the relatively widespread distribution of the species, being found on the islands of $\mathrm{O}^{\prime} \mathrm{ahu}$, Maui, and Moloka'i.

DIAGNosis. This species resembles $A$. $b a-$ waiiensis in similarity in the shape and organization of the internal palpal structures but can be distinguished in males by the relatively shorter length of the embolus (Figures 10, 23), which makes less than a complete turn. The tip of the embolus is similar in both species, coming to a point at the opening. The theridiid tegular apophysis in $A$. laba, n. sp., is broader, with a frayed, rather than raised, texture at the tip. The median apophysis is similar in both species. Males of $A$. laba, n. sp., have a shallow carapace, more pronounced cephalic groove, and relatively long fangs when compared with $A$. hawaiiensis. Females are distinguished by a single backward turn of the copulatory ducts that does not form a complete loop as in the other endemic Hawaiian species.

DESCRIPTION. Holotype male (врвм 17201) (Figures 8-11, 23): Carapace dark brown, lighter toward center, legs light brown alternating with dark brown stripes. Length from dorsal surface of carapace to cephalic groove approximately one-third length from groove to ventral margin of clypeus. Cephalic groove pronounced, appearing almost as a pit in lateral view. Fangs long, approximately twice height of carapace. Carapace approximately as wide as abdomen. Abdomen dark brown to black on sides, with distinctive silver and black lateral striping on dorsal surface and dotted with small silvery patches on sides. Abdomen slightly longer than carapace and round. Embolus wide at 


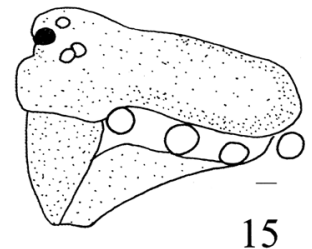

15

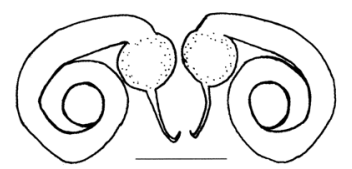

19

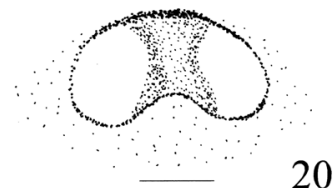

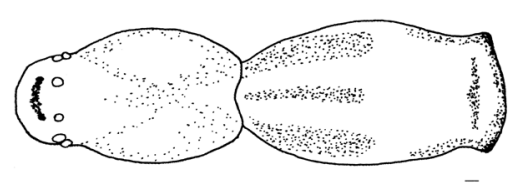

17
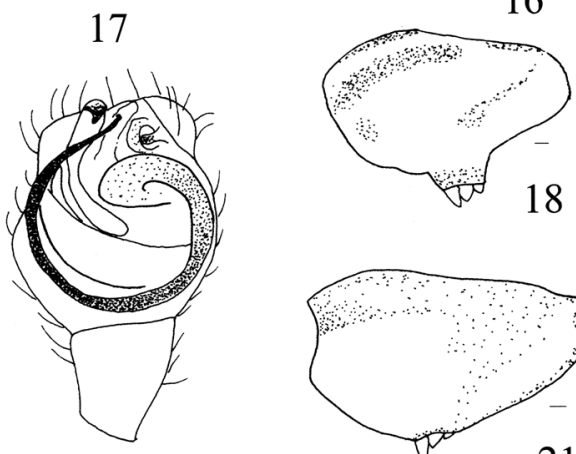

18

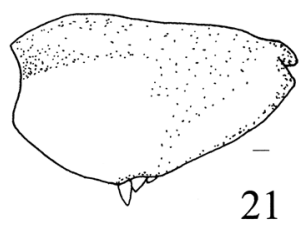

Figures 15-21. Argyrodes ilipoepoe Rivera and Gillespie, n. sp., from Hawai'i. 15-18. Male holotype: (15) cephalothorax in retrolateral view, (16) carapace in dorsal view, (17) left palp in ventral view, (18) abdomen in retrolateral view. 19-21. Female allotype: (19) genitalia in dorsal view, (20) epigynum in ventral view, (21) abdomen in retrolateral view. Scale bars equal $0.1 \mathrm{~mm}$.

base, gradually narrowing toward tip, surface serrated. Theridiid tegular apophysis extends upward and angles slightly toward prolateral side, tip curled forward. TL, 2.9; CL, 1.2; AL, 1.6; FeI, 3.5; FeII, 3.2; FeIII, 3.0; TaI, 1.8 .

Allotype female (Figures 12-14): Female nearly equal in size to male, with similar dark brown coloring on carapace, dark brown and silver patterns on abdomen, and light brownish to yellow and dark brown striping on legs. Cephalic groove less pronounced than in male, appearing as depression rather than distinct pit in lateral view. Abdomen ending in point, giving more triangular shape. Epigynum lightly sclerotized, with copulatory orifices in incomplete circle. Copulatory ducts short, having single incomplete turn. Conspicuous epigynal plug red, slightly obstructing external view of copulatory orifices. TL, 2.8; CL, 1.1; AL, 1.2; FeI, 2.3; FeII, 2.3; FeIII, 2.1; TaI, 1.2.

VARIATION. Individuals may vary in color and pattern of black and silver patches, overall size, and shape of abdomen. In particular, Maui and Moloka'i populations tend to be a darker brown, almost black, whereas the O'ahu populations appear to be lighter brown to yellow. Most individuals have silvery and black patches on the abdomen, although positions of the patches vary quite extensively. The female abdomen can be either triangular or rounded. Females, if recently fertilized, have a very obvious, bright red epigynal plug protruding outward. Size ranges (males): TL, 2.3-2.9; CL, 1.2-1.3; AL, 1.1-1.5; FeI, 3.04.5; FeII, 3.0-4.5; FeIII, 3.0-4.2; TaI, 1.72.0; (females): TL, 1.8-3.4; CL, 0.7-1.4; AL, 1.0-1.2; FeI, 2.1-3.3; FeII, 2.0-3.3; FeIII, 1.8-3.0; TaI, 0.8-1.8.

Distribution. This species is found on the islands of O'ahu, Maui, and Moloka'i.

HaвiтAт. Occurs in both wet and mesic forests.

Argyrodes ilipoepoe Rivera and Gillespie, n. sp. Figures 15-21, 24

TYPE MATERial. Holotype male (врвм 17200): Nu'alolo Trail, Kōke'e $\left(22.13^{\circ} \mathrm{N}\right.$, $\left.159.66^{\circ} \mathrm{W}, 1,070 \mathrm{~m}\right)$, Kaua'i Island, Hawai'i, USA, A. Asquith, B. Thorsby, K. Chai, Z. 
Flores, C. Rivera, 8 January 1998. Allotype female: Ku'ia Natural Area Reserve, Kōke'e $\left(22.14^{\circ} \mathrm{N}, 159.68^{\circ} \mathrm{W}, 917 \mathrm{~m}\right)$, Kaua'i Island, M. Rivera and B. Thorsby, 9 May 1997. Paratypes: Kaua'i Island: Nu'alolo Trail, Kōke'e $\left(22.13^{\circ} \mathrm{N}, 159.66^{\circ} \mathrm{W}, 1,070 \mathrm{~m}\right)$, A. Asquith, B. Thorsby, K. Chai, Z. Flores, C. Rivera, 1 August 1998 (1 male). Mōhihi Road, Kohua Trail Head, Kōke'e $\left(22.12^{\circ} \mathrm{N}, 159.62^{\circ} \mathrm{W}\right.$, $1,070 \mathrm{~m}), \mathrm{A}$. Asquith and M. Heddle, 28 December 1997 (1 male). Ku'ia Natural Area Reserve $\left(22.14^{\circ} \mathrm{N}, 159.68^{\circ} \mathrm{W}, 917 \mathrm{~m}\right), \mathrm{M}$. Rivera and B. Thorsby, 9 May 1997 (1 female). Kumuwela Road $\left(22.13^{\circ} \mathrm{N}, 159.64^{\circ}\right.$ W, 1,125 m), C. Ewing (1 female).

etymology. The specific epithet, regarded as a noun in apposition, is made up of a combination of two Hawaiian words: 'ili, meaning hose, and poepoe, meaning circular, which refers to the long and winding shape of the embolus, a feature that clearly distinguishes the male of this species from the other two species of endemic Hawaiian Argyrodes.

Diagnosis. This species resembles $A$. $b a-$ waiiensis in similarity in the shape of the carapace and length of the fangs, but the male can easily be distinguished by the very long and winding embolus, which has a smooth surface (Figures 17, 24). The embolus opening is rounded and splayed, as opposed to pointed in both $A$. laba, n. sp., and $A$. hawaiiensis. The theridiid tegular apophysis is the narrowest of all three species, with a relatively smooth, as opposed to textured or frayed, tip. The median apophysis is similar in all three species. Females can be distinguished by long ducts with two loops.

DESCRIPTION. Holotype male (врвм 17200) (Figures 15-18, 24): Carapace dark brown, lighter toward center, legs dark brown. Distance from dorsal surface of carapace to cephalic groove approximately equal to distance from groove to ventral margin of clypeus. Cephalic groove unpronounced, appearing as small recessed bump in lateral view. Fangs short, approximately equal to height of carapace. In dorsal view, carapace approximately equal in width, at widest point, to that of abdomen. Abdomen dark brown to black on sides, dorsally silver with three ellip- tical black patches extending from front to middle and dotted with small silvery patches on sides. Abdomen slightly longer than carapace and elliptical, with slight indentations toward back end when viewed dorsally. Embolus long, smooth, and narrow, with flared tip. Theridiid tegular apophysis extends upward and angles slightly to prolateral, with pointed tip curled forward. TL, 3.2; CL, 1.5; AL, 1.6; FeI, 3.3; FeII, 3.4; FeIII, 2.0; Ta I, 0.8 .

Allotype female (Figures 19-21): Female with dark brown coloring on carapace as in male, lighter toward center. Legs light brown to yellow. Abdomen elliptical with pronounced notch at back, forming two tubercles. Epigynum heavily sclerotized around margin but incomplete around copulatory orifices. Hourglass-shaped sclerotization separates genital openings. Copulatory ducts to seminal receptacles lightly sclerotized, leading to small seminal receptacles by two complete turns. Fertilization ducts long, approximately 1.5 length of diameter of seminal receptacles. TL, 2.8; CL, 1.2; AL, 1.6; FeI, 2.2; FeII, 2.9; FeIII, 1.5; TaI, 0.9.

VARIATION. Individuals may vary in color and patterns of black and silver patches, overall size, and shape of abdomen. Some individuals have nearly no silvery color, many females have dark reddish hue, and some males are very dark brown, nearly black. End of abdomen in females may be notched or rounded. Size ranges (males): TL, 2.5-3.2; CL, 1.2-1.5; AL, 1.3-1.5; FeI, 2.6-3.3; FeII, 2.6-3.4; FeIII, 1.6-2.0; TaI, 0.8-0.9; (females): TL, 2.8-4.0; CL, 1.1-1.2; AL, 1.6-2.7; FeI, 2.2-2.6; FeII, 2.3-2.9; FeIII, 1.4-1.5; TaI, 0.7-0.9.

Distribution. This species has only been found on the island of Kaua' $i$.

haвiтat. Occurs in wet and mesic forests.

\section{DISCUSSION}

\section{Species Group Affinities}

The three species of Hawaiian kleptoparasitic Argyrodes have clear morphological affinities with Argyrodes of Exline \& Levi, 1962, particularly in the organization of the internal 

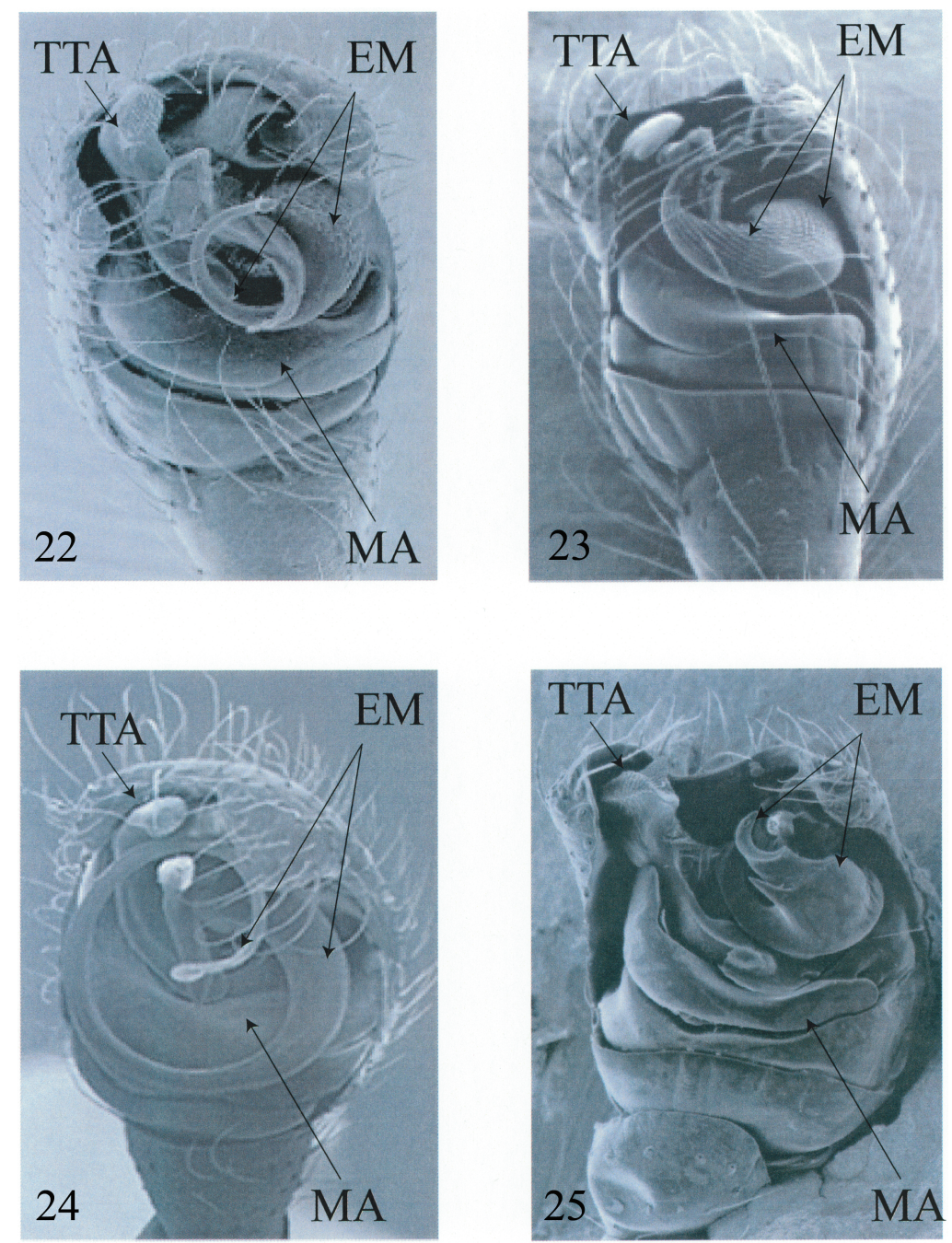

Figures 22-25. SEM photographs of Argyrodes spp. from Hawai'i, male palp. (22) Argyrodes hawaiiensis, ventral view. (23) Argyrodes laha, n. sp., paratype. (24) Argyrodes ilipoepoe, n. sp., paratype. (25) Argyrodes argentatus. TTA, theridiid tegular apophysis; EM, embolus; MA, median apophysis.

palpal structures of the males and the shape and position of the embolus. The theridiid tegular apophysis (Coddington 1990) of the Hawaiian species also projects outward; however they lack cephalic and clypeal projections typical of other representatives of the genus. In females, the epigynes of two of the Hawaiian species are heavily sclerotized, but the third is not, and all three species have curving seminal receptacles and ducts.

\section{Natural History}

All the Hawaiian species described here, like many species in the genus and indeed the subfamily, are kleptoparasitic. To date, the Hawaiian Argyrodes have been found only on the large sheet webs of spiders from the endemic genus Orsonwelles Hormiga (Linyphiidae) (Hormiga 2002, Hormiga et al. 2003). Typically, 10 to 25 individuals have been 


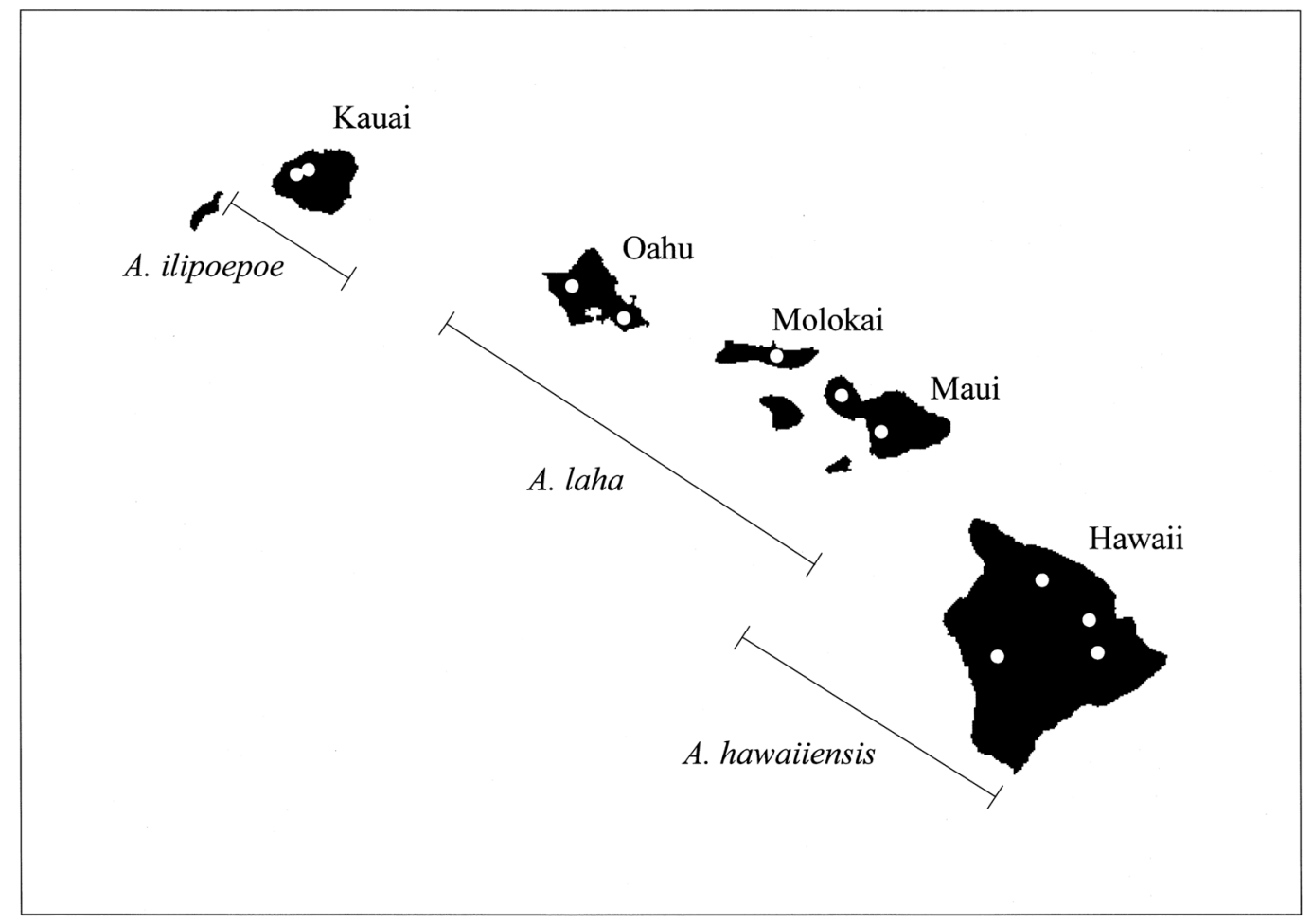

FIgURE 26. Map of collection localities of endemic Argyrodes spiders of the Hawaiian Islands.

found to inhabit a host web at a given time. However in some populations, particularly those found in East Maui, A. laba forms far more dense aggregations, with as many as 60 individuals per host. Argyrodes species tend to reside mostly on the upper scaffolding of the linyphiid sheet web while the host Orsonwelles itself usually hangs from the underside. The introduced species Argyrodes argentatus frequently co-occurs with the endemic Argyrodes on these host webs but is also commonly found on webs of other nonnative orb weavers in Hawai'i such as Argiope and Gasteracantha. Endemic Argyrodes species have never been observed on introduced spiders' webs. Argyrodes argentatus can be easily identified because it is clearly morphologically distinct from the Hawaiian endemics in both body form and genitalic shape. In particular, $A$. argentatus possesses a pronounced head tubercle and a sharp spikelike protrusion on the embolus (Figure 25).

\section{Distribution}

Endemic species of kleptoparasitic Argyrodes are found on all the main Hawaiian Islands (Figure 26). Compared with the closely related Ariamnes, which appear to have undergone an adaptive radiation (Gillespie and Rivera 2007), the Hawaiian Argyrodes are very limited in diversity. With only three species, two are found each on a single island ( $A$. bawaiiensis on Hawai'i Island and $A$. ilipoepoe on Kaua $i$ ) and the third is found in the closely situated islands of Maui, Moloka'i, and $\mathrm{O}^{\prime}$ ahu. Why this group has not diversified like Ariamnes is not known, but it may be related to ecological constraints on mor- 
phology due to their probable obligate kleptoparasitic lifestyle.

\section{ACKNOWLEDGMENTS}

I am grateful to the following for help in collecting specimens: Mandy Heddle, Bonnie Thorsby, Rosemary Gillespie, Miquel Arnedo, Alfred Rivera, Curtis Ewing, Adam Asquith, Andrew Bohonak, Koa Chai, Kerri Fay, B. Stevens, Zandra Flores, Cherry Rivera, Hank Oppenheimer, J. Scott Meidell, Randy Bartlett, and David Preston. Thanks also to Sabina Swift for assistance in obtaining type specimens, Herb Levi for valuable insight, Rosie Gillespie for helping with editing, and the following organizations for providing access to collection localities: Department of Land and Natural Resources, State of Hawai'i; The Nature Conservancy of Hawai'i; West Maui Land and Pineapple Company; and Hawai'i Volcanoes National Park.

\section{Literature Cited}

Agnarsson, I. 2004. Morphological phylogeny of cobweb spiders and their relatives (Araneae, Araneoidea, Theridiidae). Zool. J. Linn. Soc. 141:447-626.

Beatty, J. A. 2000. Additions and corrections to the spider fauna of Hawaii. Bishop Mus. Occas. Pap. 64:32-39.

Cambridge, F. O. P. 1880. On some new and little known spiders of the genus $A r$ gyrodes. Proc. Zool. Soc. Lond. 1880:320342 .

. 1897. Arachnida. Araneidea and Opiliones. Pages 1-40 in Biologia CentraliAmericana, Zoology. Vol. 2. London.

Cangialosi, K. R. 1997. Foraging versatility and the influence of host availability in Argyrodes trigonum (Araneae, Theridiidae). J. Arachnol. 25:182-193.

Chrysanthus, F. 1963. Spiders from South New Guinea. V. Nova Guinea, Zool. 24:727-750.

Coddington, J. A. 1990. Ontogeny and homology in the male palpus of orb-weaving spiders and their relatives with comments on phylogeny (Araneoclada Araneoidea Deinopoidea). Smithson. Contrib. Zool. 496:1-52.

Exline, H., and H. W. Levi. 1962. American spiders of the genus Argyrodes (Araneae, Theridiidae). Bull. Mus. Comp. Zool. 127:75-202.

Garb, J. E. 1999. An adaptive radiation of Hawaiian Thomisidae: Biogeographic and genetic evidence. J. Arachnol. 27:71-78.

Gillespie, R. G. 1991. Hawaiian spiders of the genus Tetragnatha. I. Spiny leg clade. J. Arachnol. 19:174-209.

- 1992. Hawaiian spiders of the genus Tetragnatha. II. Species from natural areas of windward East Maui. J. Arachnol. 20:117.

1994. Hawaiian spiders of the genus Tetragnatha. III. Tetragnatha acuta clade. J. Arachnol. 22:161-168.

- 1999. Naivete and novel perturbations: Conservation of native spiders on an oceanic island system. J. Insect Conserv. 3:263-272.

. 2002. Hawaiian spiders of the genus Tetragnatha. IV. New, small species in the spiny leg clade. J. Arachnol. 30:159-172.

. 2003. Hawaiian spiders of the genus Tetragnatha. V. Elongate web-builders from Oahu. J. Arachnol. 31:8-19.

Gillespie, R. G., and M. A. J. Rivera. 2007. Free-living spiders of the genus Ariamnes (Araneae, Theridiidae) in Hawaii. J. Arachnol. 35:11-37.

Gillespie, R. G., M. A. J. Rivera, and J. E. Garb. 1998. Sun, surf and spiders: Taxonomy and phylogeography of Hawaiian Araneae. Pages 41-51 in P. A. Sheldon, ed. 17th European Colloquium of Arachnology. British Arachnological Society, Burnham Beeches, Bucks, Edinburgh.

Hormiga, G. 2002. Orsonwelles, a new genus of giant linyphiid spiders (Araneae) from the Hawaiian Islands. Invertebr. Syst. 16:369-448.

Hormiga, G., M. Arnedo, and R. G. Gillespie. 2003. Speciation on a conveyor belt: Sequential colonization of the Hawaiian Islands by Orsonwelles spiders (Araneae: Linyphiidae). Syst. Biol. 52:70-88.

Karsch, F. 1880. Mittheilung über die von 
Herrn Dr. O. Finsch während seiner polynesischen Reise gesammelten Myriopoden und Arachniden. Sitzungsber. Ges. Naturforsch. Freu. Berl. 1880:77-83.

Lehtinen, P. T. 1993. Polynesian Thomisidae: A meeting of Old and New World groups. Mem. Queensl. Mus. 33:585-591.

Okuma, C. 1988. Re-descriptions of the Hawaiian spiders of Tetragnatha described by Simon (Araneae, Tetragnathidae). J. Fac. Agric. Kyushu Univ. 33:77-86.

Perkins, R. C. L. 1913. Introduction. Pages xv-ccxxviii in D. Sharp, ed. Fauna Hawaiiensis. Cambridge University Press, Cambridge.

Simon, E. 1900. Arachnida. Pages 443-519, pls. 415-419 in D. Sharp, ed. Fauna Ha- waiiensis. Cambridge University Press, Cambridge.

Suman, T. W. 1970. Spiders of the family Thomisidae in Hawaii. Pac. Insects 12:773-864.

Whitehouse, M. E. A. 1987. "Spider eat spider": The predatory behavior of Rhomphaea sp. from New Zealand. J. Arachnol. 15:355-362.

Yoshida, H. 2002. A revision of the Japanese genera and species of the subfamily $\mathrm{Ha}-$ drotarsinae (Araneae: Theridiidae). Acta Arachnol. 51:7-18.

Zhu, M. S., and D. X. Song. 1991. Notes on the genus Argyrodes from China (Araneae: Theridiidae). J. Hebei Pedagogic Coll. (Nat. Sci.) 1991:130-146. 
